\title{
Ortaöğretim Öğretmenlerinin Özerklik Davranışları ile İş Doyumları Arasındaki İlişki ${ }^{1}$
}

\author{
DOI: 10.26466/opus.650115 \\ $*$ \\ Caner Sentürken*- Aytunga Oğuz ** \\ * Öğretmen, Milli Eğitim Müdürlüğü, Balıkesir/Türkiye \\ E-Posta: caner-senturken@hotmail.com \\ ORCID: 0000-0003-3958-8756 \\ ** Prof. Dr., Kütahya Dumlupınar Üniversitesi, Eğitim Fakültesi, Kütahya/Türkiye \\ E-Posta: aytunga.oguz@dpu.edu.tr \\ ORCID: 0000-0003-1815-6866
}

\section{Öz}

Bu araştırmada öğretmenlerin özerklik davranışları ile iş doyumları arasındaki ilişkinin belirlenmesi amaçlanmıştır. Araştırma tarama modelindedir. Araştırmanın örneklemi Balıkesir ilindeki kamu ortaöğretim kurumlarında görev yapan 354 öğretmenden oluşmaktadır. Araştırmada veri toplama aracı olarak Öğretmen Özerkliği Ölçeği ve İş Doyum Ölçeği kullanılmıştır. Araştırmada betimsel istatistikler, karşılaştırmalar için t testi, ANOVA, Mann Whitney U ve Kruskal Wallis $H$ testleri ve çoklu regresyon analizi kullanılmıştır. Araştırmadan elde edilen bulgulara göre öğretmenlerin genel özerklik davranışları orta düzeyin üzerindedir. Öğretmenler özerklik davranışları arasında en yüksek katılımı sırası ile mesleki iletişim özerkliği, öğretme süreci özerkliği, öğretim programı özerkliği ve mesleki gelişim özerkliği boyutlarında göstermektedir. Öğretmenlerin özerklik davranışları; cinsiyet, eğitim durumu, branş, kıdem, yaş ve çalışılan okul türü değişkenlerine göre bazı boyutlarda istatistiksel olarak anlaml farklllı gösterirken; haftalı ders yükü ve okuldaki hizmet süresi değişkenlerine göre istatistiksel olarak anlaml farklılık göstermemektedir. Öğretmenler orta düzeyin biraz üzerinde iş doyumuna sahiptirler. Öğretmenlerin iş doyumlarl; cinsiyet değişkenine göre istatistiksel olarak anlamlı farklılık gösterirken; dĭğer değişkenlere göre istatistiksel olarak anlamlı farklllk göstermemektedir. Öğretmenlerin mesleki iletişim özerkliği, mesleki gelişim özerkliği ve öğretme süreci özerkliği ile iş doyumu arasında pozitif ve orta; öğretim programı özerkliği ile iş doyumu arasında pozitif ve düşük düzeyde ilişki bulunmuştur. Mesleki iletişim özerkliği ve mesleki gelişim özerkliği öğretmenlerin iş doyumlarının anlamlı yordayıcılarıdır.

Anahtar Kelimeler: İş doyumu, ortaöğretim, öğretmen, öğretmen özerkliğ $i$

\footnotetext{
${ }^{1}$ Bu çalışma, Prof. Dr. Aytunga OĞUZ danışmanlığında Caner ŞENTÜRKEN tarafından hazırlanan yüksek lisans tezinden üretilmiștir.
} 


\title{
The Relationship Between Secondary School Teachers Autonomy Behaviour And Job Satisfaction
}

\begin{abstract}
In this study, it is aimed to determine the relationship between teacher autonomy and job satisfaction of the teachers. Research is based on the survey model. As a sample, 354 teachers from different schools of the Balikesir city have participated. As a data collecting method, Teacher Autonomy Scale and Job Satisfaction Scale are used. Descriptive statistics and for comparisons; $t$ tests, ANOVA, Mann Whitney $U$ and Kruskal Wallis $H$ and multiple regression analysis are used. Based on the findings of the research, general teacher autonomy behaviors are greater than the middle level. Among the teacher autonomy behaviors, the most participated ones are professional communication autonomy, teaching process autonomy, curriculum autonomy and professional development autonomy. Teachers' autonomy behavior, according to the school type parameters, gender, educational background, branch, seniority and age indicate meaningful difference in terms of statistically. On the other hand, according to the weekly course load and period of service in the school, do not. Teachers have more job satisfaction compared to middle level. Teachers' job satisfaction, according to the gender show reasonable variation as a statistical data; however, according to other variables, do not. It is found that there is a positive and middle relation among communication autonomy of the teachers, professional development autonomy and teaching process autonomy and job satisfaction. Also, positive and low level connection between curriculum autonomy and job satisfaction is established. Professional communication autonomy and professional development autonomy are meaningful predictors of the job satisfaction of the teachers.
\end{abstract}

Keywords: Job Satisfaction, teacher, teacher autonomy 


\section{Giriş}

Örgütlerin belirledikleri hedeflere ulaşabilmeleri çalışanlarının etkili ve verimli çalışabilmelerini sağlamalarıyla gerçekleşebilir. Bunun için örgütler hedefleri doğrultusunda etkililiklerini ve verimliliklerini arttırmaya gayret ederken bir yönden de çalışanlarının ihtiyaçlarını dikkate almak ve örgütün bir parçası olduklarından dolayı onların memnun olmalarını sağlamak durumundadır (Yilmaz ve Altınkurt, 2012). Her meslek grubunun olanakları ve çalışanlarını doyuma ulaştırması farklılık gösterebilir. Öğretmenlerin iş doyumlarını etkileyen birçok değişken bulunmaktadır. Bu değişkenlerden birisinin de öğretmen özerkliği olduğu söylenebilir.

\section{Öğretmen Özerkliği}

Geçmişten günümüze eğitimin niteliğinin geliştirilmesi amacına dönük olarak; eğitim örgütlerine daha fazla özerklik verilmesi, yetki aktarımının yapılması ve öğretmenlerin yetkilendirilmesi gibi eğilimler ortaya çıkmıştır (Ada ve Şahin, 2007). Little (1995) öğretmen özerkliğini öğretmenin kendisinin bizzat yönettiği profesyonel olarak eylemde bulunabilme kapasitesi olarak belirtmiştir. Friedman'a (1999) göre öğretmen özerkliği, öğretmenlerin eğitimi planlayabilmeleri, geliştirebilmeleri ve düzenleyebilmeleri aynı zamanda yönetim süreçlerine katılabilmelerini öngören yetkilerini ifade eder.

Alan yazında öğretmen özerkliğinin farklı işlevleri olduğu görülmektedir. Öğretmenlere yetki ve özerklik verilmesi potansiyellerini açı̆̆a çıkarmanın yanında görev yaptıkları okula karşı bağlılıklarını arttırabilmekte (Koçak, 2011), öğrencilerinin öğrenmeleri için daha yapıcı kararlar almalarını sağlamakta (Dee, Henkin ve Singleton, 2006) ve bu durum okul için de önemli görülmektedir (Short, 1994). Öğretmen özerkliği öğrencilerin başar1larını da etkilemektedir (Ayral ve diğerleri, 2014). Özerklik düzeyi yüksek olan öğretmenler öğrencilerinin öğrenmelerinden kendilerini sorumlu hissederek gerekli düzenlemeleri yapabilmektedir.

Öğretmenlerin özerklik davranışlarını geliştirici etkenler olduğu gibi s1nırlayıcı etkenler de bulunmaktadır. Ingersoll (2007) çok fazla dışsal denetimin öğretmenlerin etkili bir şekilde çalışmaları için ihtiyaç duydukları gücü ve esnekliği onlardan alabildiğini ve öğretmenlerin motivasyonlarını 
düşürebildiğini, Benson (2010) ise evrak işlerinin öğretmenlerin özerklik davranışlarını sınırlandırabildiğini belirtilmektedir. Ayrıca öğretmenler için alınan merkeziyetçi kararların öğretmenlerin mesleki özerkliklerini zayıflattığına işaret edilmektedir (Rosenholtz, 1987; akt: Archbald ve Porter, 1994).

Öğretmen özerkliği alan yazında farklı boyutlarda ele alınmıştır. Öğretmen özerkliğinin kapsam ve boyutları Öztürk'e (2011) göre öğretimin planlanması ve uygulanması, yönetim süreçlerine katılma ve mesleki gelişim süreçleri olmak üzere üç boyutta toplanmıştır. Bazı araştırmacılar ise öğretmen özerkliğini iki boyutta ele almışlardır. Örneğin, Friedman (1999) pedagojik ve yönetimsel özerklik olarak; Pearson ve Hall (1993) genel özerklik ve program özerkliği olarak; Smith (2003) mesleki eylem ve mesleki gelişim olarak incelemiştir. Çolak ve Altınkurt (2017) ise araştırmasında öğretmenlerin özerklik davranışlarını dört boyutta incelemiştir: Öğretme süreci özerkliği; öğretmenler, alanlarının uzmanları olarak öğrenme süreçlerini kendi tercihlerine göre düzenleyebilmelidir (Pearson ve Moomaw, 2005). Öğretmenlerin en geniş özerklik boyutuna sahip olduğu bölüm sınıf içi ögretim faaliyetleriyle ilgili kısımlardır (Anderson, 1987). Bu sebepten dolayı öğretim esnasında öğretmenlerin gerekli yöntem ve teknikleri seçme konusunda gerekli mesleki bilgi ve becerilere sahip olması gerekmektedir (Öztürk, 2011). Öğretmenlerin kazanımlara ayıracakları zamanı kendilerinin belirleyebilmeleri, öğretim esnasındaki yöntem ve tekniklerin seçimi, öğrencilerin değerlendirilmesi ve ödevlendirilmesi bu boyutta değerlendirilebilir (Çolak ve Altınkurt, 2017). Öğretim programı özerkliği; öğretim programları oluşturulurken öğretmenlere yeterli özerklik verebilecek esneklikte olması gerekmektedir. Oluşturulacak bu öğretim programının tam anlamıla uygulamaya geçebilmesi öğretmenlerin karar verme ve yetki alanının geliştirilmesine bağlıdır. Öğretmenin program geliştirme çalışmalarına daha fazla katılımı, öğrencilerin özel gereksinimlerine daha uygun program ve materyallerin oluşumunu sağlamıştır (White, 1992). Bu boyutta öğretmenlerin programı kendilerine göre planlayabilmeleri, gerekli ekleme ve çıkarmaları yapabilmeleri, öğretmenlerin öğretim esnasında uygun materyal ve kaynakları seçebilmeleri incelenebilir (Çolak ve Altınkurt, 2017). Mesleki gelişim özerkliği; öğretmenlerin kendilerince gerekli gördükleri hizmet içi eğitimlere istedikleri zaman katılabilmeleri, eğitim konularına kendilerinin karar verebilmeleri ve alanın ilgilendiren bilimsel toplantılara katılabilmeleri bu boyutta incelenebilir (Çolak ve Altınkurt, 2017). Seferoğlu'na (2004) göre iyi 
bir eğitimci kendini mesleği ve kişiliği ile ilgili olarak devamlı geliştirme eğiliminde olan ve bu geliştirmeyi sağlayacak olanakları araştıran ve değerlendiren kişidir. Öğretmenlerin kendilerini geliştirebilmelerinin ön koşulunun bir boyutu özerk çalışma ortamlarının sağlanmasıdır. Öğretmenin mesleğinde sahip olacağı otorite ve özerklik ise öğretmenin gelişimi için gerekli iklimi ve ortamı sağlayacaktır (Yaylacı, 2013). Mesleki iletişim özerkliği; öğretmenlerin okul içinde olan toplantılarda düşüncelerini özgürce söyleyebilmeleri, meslektaşlarıyla ve velilerle iletişimde özerk davranabilmeleri bu boyutta incelenebilir (Çolak ve Altınkurt, 2017). Bu araştırmada da öğretmen özerkliği bu dört boyuta uygun olarak incelenmiştir. Öğretmenlerin bu boyutlarda özerk davranışlar sergilemesi bulundukları örgütlerde iş doyumlarını ve çalışma performanslarını artırabilir.

\section{İş Doyumu}

Locke iş doyumu kavramını "bireyin mesleğini ya da mesleğiyle ilgili yaşantısını hoşnutluk veren veya olumlu duygular uyandıran bir durum şeklinde takdir etmesi" olarak ifade etmiştir (Akt: Çetinkanat, 2000). Luthans'a (2011) göre iş doyumu, çalışanların kendileri için önemli gördüğü beklentileri ne kadar karşıladığına ilişkin oluşturdukları algıdır. Spector (1997) açısından ise iş doyumu bireylerin meslekleri ve işlerinin farklı yönleri hakkında nasıl hissettikleridir. Bu tanımlamalar iş doyumunun bireyin iş ortamında geçirdiği yaşantılar sonucu oluşan işiyle ilgili olumlu hisleri, duyguları ya da algılarına işaret etmektedir.

Çalışan işinden doyum sağlayamazsa ya da çalışanın doyumu istediğ $i$ seviyede değilse bir takım olumsuzluklar meydana gelebilir (Keser, 2006). Çalışanın iş doyumu elde edememesi işe geç kalma, işe devam etmeme, sik sık iş değişikliği ve performansta azalma gibi sonuçlar doğurabilir (Ĕ̆inli, 2009). Eğitim örgütlerinde, öğretmenlerin iş doyumlarının düşük olması yalnızca kendilerini değil aynı zamanda görev yaptıkları örgütleri etkileyebilmektedir. Öğretmenlerin iş doyumları okulların başarıları için önem arz etmektedir (Yılmaz ve Izgar, 2009). Bu sebepten öğretmenlerin yüksek iş doyumlarına sahip olmaları öğrencilerin başarıları ve eğitim örgütlerinin amaçlarına ulaşabilmeleri için önemlidir.

Bireyin iş doyumunun yüksek olmasını sağlamak birçok açıdan önem taşıdığı halde bu çok da kolay olmamaktadır. Çünkü iş doyumu çok boyutlu ve karışık bir kavramdır. İş doyumu kapsamında; ücret, iş arkadaşları, 
örgüt ve yönetim, çalışma koşulları, işin niteliği gibi farklı boyutların dikkate alınması gerekmektedir (Özgüven, 2003). Öğretmenlerin iş doyumlarını (Cerit, 2009) etkileyebilen çeşitli değişkenlerden biri de özerkliktir.

Araştırmalar öğretmen özerkliğinin öğretmenlerin iş doyumlarında etkili bir değişken olduğuna işaret etmektedir. İşteki özerklik çalışanların motivasyonların etkilemektedir (Campion ve Thayer, 1987). Parker'in (1991) araştırmasında da öğretmenler kendilerini motive eden on faktörden biri olarak özerkliği sıralamışlardır (Akt: Ulriksen, 1996). Bazı araştırmalarda öğretmen özerkliği ile iş doyumu arasında anlamlı ve pozitif bir ilişki olduğunu gösteren sonuçlar elde edilmiştir (Bogler 2001; Brunetti, 2001; Street ve Licata, 1988, akt: Kim ve Loadman, 1994). Yüksek iş doyumuna sahip öğretmenlerin mevcut özerklik düzeylerinin diğerlerine göre daha yüksek olduğu (Pearson ve Hall, 1993) ve öğretmen özerkliğinin öğretmenlerin iş doyumların arttırmada önemli bir etken olduğu (Lawson, 2004) belirtilmektedir.

Öğretmen özerkliği kavramı ve öğretmen özerkliğine etki eden unsurlar Avrupa ve Amerika'da uzun zamandır üzerinde çalışlan kavramlardır (Brunetti, 2001; Friedman, 1999; Koustelios, Karabatzaki ve Kousteliou, 2004; Kuku ve Taylor, 2002; Liu, 2007; Pearson ve Hall, 1993; Pearson ve Moomaw, 2005; Porter, 1963). Türkiye de ise bu konuda yapılan araştırmaların sayısı artmakla beraber hala sinırlı sayıdadır.

Alan yazında iş doyumu kavramı ile ilgili kuramsal çalışmaların (Spector, 1997) yanı sıra çalışanların iş doyum düzeylerini belirleyen ve bireysel ve örgütsel unsurlara göre farklılıkları belirleyen çok sayıda araştırmaya rastlanmıştır (Ayan, Kocacık ve Karakuş 2009; Bernal ve diğerleri, 2005; Graham ve Messner, 1998; Hackman ve Oldham, 1975; Koruklu ve diğerleri, 2013; Oshagbemi, 2000; Şahin, 2013; Taşdan ve Tiryaki, 2008). Alan yazında aynı zamanda iş doyumu kavramı ile eğitim yönetimine uygulanması (BalCl, 1983), tükenmişlik ve kişilik özellikleri (Akçamete, Kaner ve Sucuoğlu, 2001), sosyal ve duygusal yalnızlık düzeyleri (Şişman ve Turan, 2004), ücret, kariyer ve yaratıclık (İmamoğlu ve diğerleri, 2004), yaşam doyumu (Avşaroğlu ve diğerleri, 2005), liderlik davranışları (Tengilimoğlu, 2005), duygusal zeka (Öztürk ve Deniz, 2008), örgütsel vatandaşlık davranışı (Yılmaz, 2012) ve mesleki profesyonellik (Altınkurt ve Yllmaz, 2014) gibi birçok değişken ile yapılan çalışmalara rastlamak mümkündür. Öğretmenlerin özerklik düzeyleri ile iş doyumu davranışlarını inceleyen sınırlı sayıda araştırmaya 
ulaşılmıştır (Çolak, Altınkurt ve Yılmaz, 2017; Koustelios, Karabatzaki ve Kousteliou, 2004; Pearson ve Moomaw, 2005; Skaalvik ve Skaalvik; 2014; Skinner, 2008).

Türkiye'deki çalışmalar incelendiğinde öğretmen özerkliği ile iş doyumu davranışlarını inceleyen bir çalışmaya (Çolak, Altınkurt ve Yılmaz, 2017) rastlanmıştır. Türkiye'de öğretmenin rolleri geleneksel olarak belirlenmiştir. Öğretmene, öğretimin içerik, yöntem, materyallerinin seçilmesinde ve planlamada tanınan yetki ve sorumluluk alanları oldukça kısıtlıdır. Öğretmenleri program geliştirebilmeye teşvik eden şartlar yok denecek kadar azdır (Öztürk, 2011). Öğretmenlerin özerk davranışlar sergilemesi ile mesleklerindeki iş doyumunun yükselebileceği ve böylece verimliliğin artabileceği düşünülmektedir. Öğretmenlerin özerklik ve iş doyumuna sahip olmaları mesleki gelişimlerini de olumlu etkileyebileceğinden bu değişkenlerin incelenmesi önemli görülmektedir. Bu gerekçelerle bu araştırmanın sonuçları alan yazına önemli katkılar sağlayabilir.

$\mathrm{Bu}$ araştırmada, ortaöğretim öğretmenlerinin özerklik davranışları ile iş doyumları arasındaki ilişkinin belirlenmesi amaçlanmıştır. Bu genel amaç doğrultusunda araştırmanın alt problemleri aşağıda belirtilmiştir.

\section{Alt problemler:}

1) Ortaöğretim öğretmenlerinin özerklik davranışları nasıldır?

2) Ortaöğretim öğretmenlerinin özerklik davranışları; cinsiyet, çalışılan okul türü, eğitim durumu, branş, haftalık ders yükü, kıdem, okuldaki hizmet süresi ve yaşa göre farklılık göstermekte midir?

3) Ortaöğretim öğretmenlerinin iş doyumları nasıldır?

4) Ortaöğretim öğretmenlerinin iş doyumları; cinsiyet, çalışılan okul türü, eğitim durumu, branş, haftalık ders yükü, kıdem, okuldaki hizmet süresi ve yaşa göre farklılık göstermekte midir?

5) Ortaöğretim öğretmenlerinin özerklik davranışları iş doyumlarını anlamlı bir şekilde yordamakta mıdır?

\section{Yöntem}

\section{Araştırmanın Modeli}

Araştırma ilişkisel tarama modelinde desenlenmiştir. Bu modele göre bir araştırmada iki ya da daha fazla değişken arasında birlikte bir değişimin 
olup olmadığı ve/ ya da derecesi belirlenmeye çalışılmaktadır (Karasar, 2013).

\section{Evren ve Örneklem}

Araştırmanın evreni, 2016-2017 eğitim öğretim yılında, Balıkesir il merkezi ve ilçelerindeki kamu ortaöğretim kurumlarında görev yapan 4535 ortaöğretim öğretmeninden oluşmaktadır. Örneklemin belirlenmesinde oransız küme örneklemesi tekniği kullanılmıştır. Evreni temsil edecek örneklem sayıs1 \%95 güven düzeyi için en az 354 olarak hesaplanmıştır. Uygulanan ölçme araçları çeşitli sebeplerle geri dönüşlerinde eksiklikler olabileceği düşüncesi ile 500 ortaöğretim öğretmenine uygulanmış ve ölçeklerin 415'i geri dönmüştür. Ancak geri dönenlerden araştırmada kullanılabilir olan 354 ölçek değerlendirmeye alınmıştır. Araştırmaya katılan öğretmenlerin \%54.5'i erkek ( $\mathrm{n}=193), \% 45.5^{\prime} \mathrm{i}$ kadındır $(\mathrm{n}=161)$. Katılımcların \%42.4'ü anadolu liselerinde $(\mathrm{n}=150), \% 26.3^{\prime} \ddot{u}$ mesleki ve teknik anadolu liselerinde $(\mathrm{n}=93), \% 11.9^{\prime} \mathrm{u}$ anadolu imam hatip liselerinde $(\mathrm{n}=42), \% 5.9^{\prime} \mathrm{u}$ fen liselerinde $(n=21), \% 3.4$ 'ü çok programlı anadolu liselerinde (n=12), \%6.2'si özel eğitim iş uygulama merkezlerinde ( $n=22), \% 2.3$ 'ü güzel sanatlar liselerinde $(n=8)$ ve \%1.7'si sosyal bilimler liselerinde $(\mathrm{n}=6)$ çalışmaktadır. Katılımcıların \%85.6'sı lisans eğitimi ( $n=303) \% 14.4$ 'ü lisansüstü eğitim $(n=51)$ görmüştür. Katılımc1ların \%86.2'si branş öğretmeni (n=305), \%13.8'i meslek dersleri $(n=49)$ öğretmenidir.

\section{Veri Toplama Araçlarn}

Araştırma verilerinin toplanmasında "Öğretmen Özerkliği Ölçeği" ile "İş Doyum Ölçeği" kullanılmıştır. Çolak ve Altınkurt (2017) tarafından geliştirilen "Öğretmen Özerkliği Ölçeği" 17 maddeden ve 4 alt faktörden oluşmaktadır. Ölçek maddeleri Likert tipi beşli derecelendirilmiştir ("1-Kesinlikle Katılmıyorum" ve "5-Kesinlikle Katılıyorum" aralığında). Ölçekten alınan puanların yüksekliği öğretmenlerin özerkliklerinin yüksekliğini ifade etmektedir. Ölçeğin Cronbach Alfa iç tutarlılık katsayısı; Öğretme Süreci Özerkliği için .82, Öğretim Programı Özerkliği için .82, Mesleki Gelişim Özerkliği için .85, Mesleki İletişim Özerkliği için .78 ve ölçeğin tümü için .89 olarak bulunmuştur. Bu çalışmada ise ölçeğin güvenilirlik katsayıları; alt boyutlara göre sırasıyla $.82, .82, .80, .71$ ve ölçeğin tümü için .89 olarak bulunmuştur. 
Araştırmada öğretmenlerin iş doyum düzeylerinin belirlenmesi için; Hackman ve Oldham (1975) tarafından geliştirilen ve Taşdan (2008) tarafından uyarlanan "İş Doyum Ölçeği" kullanılmıştır. Ölçek, tek faktörlü olup Likert tipi beşli derecelenmiş ("1-Beni hiç tatmin etmez" ve "5-Beni çok tatmin eder" aralığında) 14 maddeden oluşmaktadır. Ölçeğin Cronbach Alfa iç tutarlılık katsayısının $.95^{\prime}$ tir. Bu çalışmada ise .88 olduğu belirlenmiştir.

\section{Verilerin Analizi}

Araştırma verilerinin analizinde betimsel istatistikler, karşılaştırmalarda $\mathrm{t}$ testi, tek yönlü varyans analizi (ANOVA), Kruskall Wallis $\mathrm{H}$ ve Mann Whitney U kullanılmıştır. Öğretmenlerin özerklik düzeylerinin iş doyumlarını anlamlı bir şekilde yordayıp yordamadığını belirlemek amacıyla çoklu regresyon analizi kullanılmıştır. Regresyon analizi öncesinde çok değişkenli normallik ve doğrusallık, çok yönlü uç değerler ve çoklu bağlantı problemleri incelenmiş ve çoklu bağlantı problemi bulunmadığı belirlenmiştir.

\section{Bulgular}

Araştırmadan elde edilen bulgulara göre öğretmenlerin genel özerklik davranışları orta düzeyin üzerindedir ( $\overline{\mathrm{X}}=3.85, \mathrm{~S}=.64)$. Öğretmenler özerklik davranışları arasında en yüksek katılımı sırası ile mesleki iletişim özerkliği $(\bar{X}=4.12, S=.74)$, öğretme süreci özerkliği $(\bar{X}=4.00, S=.70)$, öğretim programı özerkliği ( $\bar{X}=3.71, S=.89$ ) ve mesleki gelişim özerkliği ( $\bar{X}=3.52, S=1.00)$ boyutlarında göstermektedir. Öğretmenlerin özerklik davranışları; cinsiyet [t(352)=2.17; $\mathrm{p}<.05]$, eğitim durumu [t(352)=2.47; $\mathrm{p}<.05]$, branş [t(352)=2.90; $\mathrm{p}<.05]$, k1dem $\left[\chi^{2}=13.18 ; \mathrm{p}<.05\right]$, yaş $\left[\chi^{2}=16.42 ; \mathrm{p}<.05\right]$ ve çalışılan okul türü $\left[\chi^{2}=19.25 ; \mathrm{p}<.05\right]$ değişkenlerine göre bazı boyutlarda istatistiksel olarak anlamlı farklılık gösterirken; haftalık ders yükü ve okuldaki hizmet süresi değişkenlerine göre istatistiksel olarak anlamlı farklılık göstermemektedir. Araştırmaya katılan öğretmenler orta düzeyin biraz üzerinde iş doyumuna $(\overline{\mathrm{X}}=3.51, \mathrm{~S}=.60)$ sahiptirler. Öğretmenlerin iş doyumları; cinsiyet $[\mathrm{t}(352)=2.59$; $\mathrm{p}<.05]$ değişkenine göre istatistiksel olarak anlamlı farklılık gösterirken; çalışılan okul türü, eğitim durumu, branş, haftalık ders yükü, kıdem, okuldaki hizmet süresi, ve yaş değişkenlerine göre istatistiksel olarak anlamlı farklılık göstermemektedir. 
Tablo 1'de öğretmen özerkliğinin, ortaöğretim öğretmenlerinin iş doyumlarını ne düzeyde yordadığını belirlemek amacıyla yapılan regresyon analizi sonuçları yer almaktadır.

Tablo 1. Öğretmenlerin İş Doyumlarının Yordanmasına İlişkin Regresyon Analizi Sonuçları

\begin{tabular}{llllllll}
\hline Değişen & $\mathbf{B}$ & Standart Hata & $\boldsymbol{\beta}$ & $\mathbf{t}$ & $\mathbf{p}$ & İkili (r) & Kısmi (r) \\
\hline Sabit & 1.76 & .19 & - & 8.90 & $.00^{*}$ & - & - \\
Ö̈̆gretme Süreci Özerkliği & .12 & .06 & .14 & 1.88 & .06 & .34 & .10 \\
Öğretim Programı Özerklĭgi & .03 & .04 & .04 & .64 & .51 & .29 & .03 \\
Mesleki Gelişim Özerkliği & .10 & .03 & .17 & 3.21 & $.00^{*}$ & .31 & .17 \\
Mesleki lletişim Özerkliği & .19 & .04 & .23 & 4.47 & $.00^{*}$ & .34 & .23 \\
\hline $\mathrm{R}=.44 \quad \mathrm{R}^{2}=.19$ & $\mathrm{~F}(4349)=21.56$, & $\mathrm{p}=.00^{*}$ & & & & & \\
\hline
\end{tabular}

${ }^{*} p<.05$

Tablo 1 incelendiğinde öğretmenlerin mesleki iletişim özerkliği ( $\mathrm{r}=.34)$, mesleki gelişim özerkliği ( $\mathrm{r}=.31)$ ve öğretme süreci özerkliği $(\mathrm{r}=.34)$ ile iş doyumu arasında pozitif ve orta; öğretim programı özerkliği ( $r=.29)$ ile iş doyumu arasında pozitif ve düşük düzeyde ilişki bulunmuştur. Mesleki iletişim özerkliği ve mesleki gelişim özerkliği öğretmenlerin iş doyumlarının anlamlı yordayıcılarıdır. Öğretmen özerkliğinin boyutları, öğretmenlerin iş doyumu düzeylerinin \%19'unu açıklamaktadır $\left[R=.44 ; R^{2}=.19 ; F_{(4-349)}\right.$ $=21.56 ; \mathrm{p}<.05]$.

\section{Tartışma ve Sonuç}

$\mathrm{Bu}$ araştırmada ortaöğretim öğretmenlerinin öğretmen özerkliği ile iş doyumları arasındaki ilişki belirlenmeye çalışılmıştır. Öğretmenlerin, genel öğretmen özerkliği davranışları orta düzeyin üzerindedir. Çolak ve Altınkurt (2017) ile Yazıcı ve Akyol'un (2017) araştırmalarında da benzer şekilde öğretmenlerin özerkliklerinin orta düzeyin üzerinde olduğu sonucu elde edilmiştir. Öğretmenler özerklik boyutları arasında en fazla mesleki iletişim boyutunda özerk davranışlar sergilemektedirler. Öğretmenlerin yapılan kurullarda görüş ve düşüncelerini özgür bir şekilde ifade edebilmeleri, okul yönetimi kararlarında daha katılımcı olduklarını göstermektedir. Aynı zamanda meslektaşlarılya ve velilerle olan iletişimlerine okul yönetiminin müdahalede bulunmaması öğretmenin mesleki açıdan daha rahat iletişim kurabilmesini sağlamaktadır. Elde edilen bulgular incelendiğinde, Türki- 
ye'de öğretmen özerkliği davranışının orta düzeyin üzerinde olması olumlu bir gelişmedir. Ancak bu özerkliğin eğitim sistemi tarafından öğretmenlere sağlanan bir özerklik olduğunu söyleyemeyiz. UNESCO'nun Küresel Eğitimi İzleme Raporu'nda (2017) Türkiye'nin, öğretmenlerin derslerin içeriklerine müdahale edebilmede en az söz sahibi olan ülkelerden birisi olduğu ve öğretmenlerin ders içeriğine karar verme özerkliğinin azaldığı belirtilmiştir. OECD (2010) raporları incelendiğinde Türkiye'nin öğrenci değerlendirme politikaları oluşturma, ders kitaplarına karar verme, ders içeriğini belirleme ve hangi derslerin verileceğine karar verme boyutlarında az özerklik sağlayan ülkelerden birisi olduğu belirtilmektedir. Bu bulgular öğretmenlerin işlerinde daha çok sorumluluk aldıkları ve işlerinde daha özverili çalışmalar ortaya koymak istedikleri sonucunu göstermektedir.

Öğretmenlerin, mesleki iletişim özerkliği cinsiyete göre anlamlı farklılık göstermektedir. Erkek öğretmenler kadın öğretmenlere göre mesleki iletişim boyutunda daha özerk davranışlar sergileyebilmektedir. Alan yazındaki araştırmalar incelendiğinde, Pearson ve Hall (1993) tarafından yapılan araştırmada öğretmenlerin özerklik davranışları cinsiyetlerine göre farkl1laşmamaktadır. Boz (2014) araştırmasında cinsiyet değişkeninin öğretmenlerin özerklik algılarını etkilemediği sonucunu elde etmiştir. Şakar (2013) tarafından İngilizce öğretmenleri üzerinde yapılan araştırmada da cinsiyetin öğretmenlerin özerklik algılarını etkilemediği sonucuna varılmıştır.

Öğretmenlerin, öğretme süreci özerkliği ve mesleki gelişim özerkliği okul türlerine göre anlamlı farklılık göstermektedir. Elde edilen puan ortalamalarına göre anadolu liselerinde çalışan öğretmenler güzel sanatlar liselerinde çalışan öğretmenlerden öğretme sürecinde daha özerk davranışlar sergilerken, mesleki ve teknik anadolu liselerinde, özel eğitim iş uygulama merkezlerinde ve fen liselerinde çalışan öğretmenlere göre öğretme sürecinde daha az özerk davranışlar sergilemektedirler. Aynı zamanda anadolu imam hatip liselerinde çalışan öğretmenler mesleki ve teknik anadolu liselerinde ve güzel sanatlar liselerinde çalışan öğretmenlere göre öğretme sürecinde daha özerk davranışlar sergilerken, özel eğitim iş uygulama merkezlerinde ve fen liselerinde çalışan öğretmenlere göre öğretme sürecinde daha az özerk davranışlar sergilemektedirler. Elde edilen puan ortalamaları incelendiğinde anadolu liselerinde çalışan öğretmenler özel eğitim iş uygulama merkezlerinde çalışan öğretmenlere göre mesleki gelişim boyutunda daha özerk davranışlar sergilerken, mesleki ve teknik anadolu liselerinde, çok 
programlı anadolu liselerinde ve fen liselerinde çalışan öğretmenlere göre mesleki gelişim boyutunda daha az özerk davranışlar sergilemektedirler. Anadolu imam hatip liselerinde çalışan öğretmenler mesleki ve teknik anadolu liselerinde çalışan öğretmenlere göre mesleki gelişim boyutunda daha özerk davranışlar sergilemektedirler. Aynı zamanda fen liselerinde çalışan öğretmenler anadolu imam hatip liselerinde ve güzel sanatlar liselerinde çalışan öğretmenlere göre mesleki gelişim boyutunda daha özerk davranışlar sergileyebilmektedir. Pearson ve Moomaw (2005) tarafindan yapilan araştırmada da benzer şekilde; öğretmen özerkliği davranışları, farklı öğretim seviyelerinden seçilen örnekleme göre karşılaştırıldığında genel öğretim özerkliği boyutunda ilkokul ve lise öğretmenleri arasında, program özerkliğinde ise ilkokul ile lise ve ortaokul ile lise arasında farklılıklar bulunmuştur. Şakar (2013) tarafından yapılan araştırmada ise ortaokul İngilizce öğretmenleri ile lise İngilizce öğretmenleri arasında öğretmen özerkliği davranışları farklılık göstermektedir. Liselerde çalışan İngilizce öğretmenlerinin ortaokullarda çalışan İngilizce öğretmenlerine göre daha yüksek özerklik algısına sahip oldukları sonucu bulunmuştur.

Öğretmenlerin, öğretmen özerkliği davranışları eğitim durumları değişkenine göre öğretme süreci özerkliği ve mesleki gelişim özerkliğine göre anlamlı farklılık göstermektedir. Lisansüstü eğitimi olan öğretmenler lisans eğitimi olan öğretmenlere göre öğretme süreci özerkliği ve mesleki gelişim özerkliği boyutlarında daha özerk davranışlar sergileyebilmektedir. Lisansüstü eğitime sahip olan öğretmenlerin farkındalıkları daha yüksek olduğundan daha fazla özerklik davranışları sergileyebilmiş olabilirler. Aynı zamanda mesleki bilgi ve öğretim yöntemleri açısından farkındalıkları daha yüksek olduğu için öğretme sürecinde daha özerk olabilmektedirler.

Öğretmenlerin, öğretmen özerkliği davranışları branş değişkenine göre öğretme süreci özerkliği ve öğretim programı özerkliğine göre anlamlı farklılık göstermektedir. Branş öğretmenleri meslek dersi öğretmenlerine göre öğretme süreci özerkliği ve öğretim programı özerkliği boyutlarında daha özerk davranışlar sergilemektedirler. Branş öğretmenlerinin meslek dersi öğretmenlerine göre öğretme sürecinde ve öğretim programında daha özerk davranışlar sergilemesinin sebebi meslek dersi öğretmenlerinin çalışma atölyelerinde belirli kurallara uymak zorunda kalarak öğretim süreçlerini devam ettirmeleri özerkliklerini kısttlyyor olabilir. 
Öğretmenlerin öğretmen özerkliği davranışları kıdem değişkenine göre öğretme süreci özerkliği ve öğretim programı özerkliğine göre anlamlı farklılık göstermektedir. 1-10 yıl kıdeme sahip olan öğretmenler, 11-20 yıl ve 21 yıl ve üzeri kıdeme sahip olan öğretmenlere göre öğretme süreci özerkliği ve öğretim programı özerkliği boyutlarında daha özerk davranışlar sergileyebilmektedir. Bu sonuçlara göre öğretmenlerin ilerleyen kıdemleri düşünüldügünde, mesleklerinde daha tecrübeli ve deneyimli olacakları böylece öğretme süreci özerkliği ve öğretim programı özerkliği boyutlarında daha özerk olmaları beklenirken ilerleyen kıdemlerinde öğretmenlerin öğretme süreci özerkliği ve öğretim programı özerkliği davranışlarının azaldığı görülmektedir. Öğretmenlerin kıdemleri ilerledikçe okul yöneticilerinin, velilerin veya meslektaşlarının olumsuz tutumları özerklik davranışlarının azalmasına neden olmuş olabilir. Aynı zamanda sistemin özerkliği sınırlayıCı uygulamaları, öğretmenlerin kıdemleri ilerledikçe özerklik davranışlarının azalmasına sebep olabilir. Çolak, Altınkurt ve Yılmaz (2017), Yazıcı ve Akyol (2017) ve Şakar (2013) tarafından yapılan araştırmalarda da öğretmenlerin mesleki kıdemleri ilerlerken özerklik davranışlarının azaldığı görülmektedir. Pearson ve Hall (1993) tarafından yapılan çalışmada ise öğretmenlerin, öğretmen özerkliği davranışları kıdemlerine göre farklılık göstermemektedir. Boz'un (2014) araştırmasında ise öğretimsel özerklik boyutunu en az benimseyip ve uygulanır bulan öğretmenler, kıdemi 1-6 yıl arasında olan öğretmen grubudur. Oysa Liu (2007) tarafından yapılan araştırmada ise mesleğinin ilk yıllarında olan öğretmenlerin okul politikalarına katılmalarının mesleklerinden ayrılma olasılıklarını azalttığı sonucunu elde etmiştir. Öğretmenlerin okul politikalarına katılabilmesi, görüş ve düşüncelerini kurullarda özgürce ifade edebilmesi mesleğinden ayrılma olasılığını azaltabilmektedir.

Öğretmenlerin, öğretme süreci özerkliği ve öğretim programı özerkliği yaş değişkenine göre anlamlı farklılık göstermektedir. Bu boyutlarda 21-30 yaş aralığında olan öğretmenler diğer yaş gruplarında olan öğretmenlere göre daha özerk davranışlar sergileyebilmektedir. Aynı zamanda 31-40 yaş aralığında olan öğretmenler 51 ve üstü yaş aralığında olan öğretmenlere göre öğretme sürecinde daha özerk davranışlar sergileyebilmektedir. Türkiye'de 2005 yılında Milli Eğitim Bakanlığı Talim ve Terbiye Kurulu Başkanlığ1 tarafından değişen öğretim programı sonrası öğrencinin bilgiyi aktif olarak kendisinin yapılandırdığı öğretim süreçlerine yönelim başladı. Milli 
Eğitim Bakanlığı ve üniversiteler ise görev yapan öğretmenleri ve öğretmen adayların bu yaklaşıma uygun şekilde yetiştirmek amaciyla gereken düzenlemeleri yaparak bu konuda eğitim vermeye başladılar (Gür, Dilci ve Arseven, 2013). Öğretmenlerin mesleklerinin ilk yıllarında daha özerk davranışlar sergilemelerinin sebebi, hizmet öncesi aldıkları eğitim dolayısıyla öğrencilerin aktif öğrenme süreçlerine rehberlik edebilmeleri için öğretme sürecinde ve öğretim programlarında özerk davranışlar sergilemeleri gerektiğinden olabilir. Boz (2014) tarafından yapılan araştırmada ise öğretmenlerin yaşları ilerledikçe öğretimsel özerkliği, mali özerkliği, kişisel ve mesleki gelişimi uygulanabilir bulma düzeyleri artarken yönetsel özerkliği uygulanabilir bulma düzeyleri azalmaktadır.

Öğretmenlerin, iş doyumları orta düzeyin biraz üzerindedir. Alan yazındaki araştırmalar incelendiğinde öğretmenlerin iş doyumunun (Altınkurt ve Yılmaz, 2014; Ayan, Kocacık ve Karakuş, 2009; Çanak, 2014; Şahin, 2013) araştırmalarında orta düzeyde oldukları; Yıldırım (2015) ise yapmış olduğu araştırmada öğretmenlerin genel iş doyumunun ortalamanın biraz üzerinde olduğu sonucunu elde etmiştir. Öğretmenlerin memnuniyet ve motivasyonlarının yüksek olması işlerini severek yapmalarını yani iş doyumlarının yüksek olması eğitim örgütlerinin amaçlarına ulaşabilmesini sağlayabilir. Bu nedenle öğretmenlerin iş doyumlarının orta düzeyde olmasıyla yetinilmeyip daha üst düzeylere çıkarılması için gerekli çabalar gösterilmelidir. Bu durumda iş doyumunu engelleyen etkenlerin belirlenmesi ve giderilmeye çalışılması önem taşımaktadır.

Öğretmenlerin iş doyumları cinsiyet değişkenine göre anlamlı farklılık göstermektedir. Erkek öğretmenlerin kadın öğretmenlere göre daha fazla iş doyumuna sahip oldukları sonucu elde edilmiştir. Bu sonuca göre cinsiyet değişkeninin öğretmenlerin iş doyumlarını etkilediği söylenebilir. Çanak, (2014) ve Kumaş ve Deniz, (2010) tarafindan yapılan çalışmalarda da öğretmenlerin iş doyumlarının cinsiyetlerine göre farklılaşttğı görülmektedir. Ancak alan yazındaki bazı araştırmalarda (Koruklu, Feyzioğlu, Özenoğlu Kiremit ve Aladağ 2013; Şahin 2013; Taşdan ve Tiryaki 2008; Yılmaz 2012) ise öğretmenlerin iş doyumlarının cinsiyetlerine göre farklılaşmadı̆̆1 görülmektedir.

Öğretmenlerin, öğretmen özerkliği davranışları ile iş doyumları arasındaki ilişkiye bakıldığında anlamlı düzeyde ilişkiler bulunmaktadır. Öğretme süreci özerkliği, mesleki gelişim özerkliği ve mesleki iletişim özerkliği ile 
iş doyumu arasında pozitif yönde ve orta düzeyde; öğretim programı özerkliği ile iş doyumu arasında pozitif yönde ve düşük düzeyde ilişkiler bulunmuştur. Diğer değişkenler kontrol edildiğinde mesleki iletişim özerkliği, mesleki gelişim özerkliği ve öğretme süreci özerkliği ile iş doyumu arasında pozitif ve düşük düzeyde ilişkiler bulunmuştur. Regresyon analizi sonuçlarına göre mesleki iletişim özerkliği ve mesleki gelişim özerkliği öğretmenlerin iş doyumunun önemli yordayıcılarıdır. Öğretme süreci özerkliği ve öğretim programı özerkliği ise öğretmenlerin iş doyumunu yordamamaktadır. Öğretmen özerkliğinin boyutları, öğretmenlerin iş doyumlarının \%19'unu açıklamaktadır. Öğretmenlerin katılacakları hizmet içi eğitimin konuların ve zamanın belirleyebilmeleri ve alanlarıla ilgili istedikleri bilimsel toplantılara katılabilmeleri iş doyumlarını arttırabilir. Aynı zamanda öğretmenler kurulunda düşüncelerini özgür şekilde ifade etmeleri ve meslektaşlarıyla ve veliler ile olan iletişimlerine okul yönetiminin karışmaması iş doyumların arttırabilir. Alan yazında daha fazla özerk davranışlar sergileyen öğretmenlerin daha fazla iş doyumuna sahip olduğunu belirten araştırmalar bulunmaktadır. Örneğin, Skaalvik ve Skaalvik (2014) tarafından yapılan araştırma sonucunda öğretmen özerkliği ile iş doyumu arasında pozitif yönde ve düşük düzeyde bir ilişki bulunmuştur. Pearson ve Moomaw (2005) tarafından yapılan araştırma sonucunda öğretmen özerkliği ile iş doyumu arasında pozitif yönde düşük düzeyde bir ilişki bulunmuştur. Kim ve Loadman (1994) araştırmasında öğretmenlerin iş doyumu için gerekli değişkenlerden birinin de özerklik olduğunu belirtmiştir. Perie ve Baker (1997) çalışmasında mesleki özerlik ile öğretmen memnuniyetinin pozitif yönde ilişkili olduğunu belirtmiştir. Al-Siyabi (2016) tarafından yapılan çalışmada ise mesleki özerklik ile mesleki doyum arasında pozitif yönde ve orta düzeyde ilişki bulunmuştur. Koustelios, Karabatzaki ve Kousteliou (2004) tarafından yapılan çalışmada ise öğretmenlerin iş doyumları ile özerklikleri arasında anlamlı ve pozitif yönde ilişki bulunmuştur.

Sonuç olarak öğretmenlerin özerklikleri iş doyumları etkileyen değişkenlerden birisidir. Öğretmenlerin öğretim programı hazırlanırken ve uygulama esnasında sürece dahil olmalarının, mesleki gelişimleri açısından katılacakları hizmet içi eğitimlerin zamanlarını kendilerinin belirlemelerinin, öğrencileri ödevlendirirken kolaylıklar sağlanmasının, veliler ile iletişim kurmalarında okul yönetiminin olumlu tutum sergilemesinin iş doyumlarını arttırabileceği söylenebilir. 


\title{
EXTENDED ABSTRACT
}

\section{The Relationship Between Secondary School Teachers Autonomy Behaviour And Job Satisfaction}

\author{
Caner Şentürken - Aytunga Oğuz \\ Ministry of National Education, Kütahya Dumlupinar University
}

Job satisfaction is one of the significant factors in terms of teacher to be able to fulfil the duties and responsibilities expected from them and be able to succeed in their professions. Job satisfaction means the compliance between the value an individual attaches to his/her job and his/her individual needs. In other words, it is the emotional satisfaction that an individual reaches as the result of his/her occupation or professional life assessment (Güler, 1990; Qtd in.: Izgar, 2000). According to Luthans (2011), job satisfaction is the perception of employees regarding to what extent they meet the expectations they consider significant for themselves. According to Spector (1997), job satisfaction is how individuals feel regarding the different aspects of their professions and jobs. The arrangement of environments that will increase the job satisfaction of teachers may affect fulfilling the objectives of schools in a positive manner. In this context, identifying the factors that may affect teachers' job satisfaction is significant. It has been noted that job satisfaction of teachers is affected by different variables such as their opinions regarding age, relationships with the colleagues at school and their level of participation in in-service training (Koruklu et al., 2013), type of school and the number of teachers at school (Altınkurt and Yilmaz, 2014). In addition to these variables, teacher autonomy could also be considered as significant. Teacher autonomy indicates teachers' being able to plan, develop and organize educational activity and their authority anticipating their ability to participate in management processes (Friedman, 1999). Little (1995) has stated teacher autonomy as the capacity to act professionally where the teacher manages him/herself. Demonstrating autonomous behaviors may increase the job satisfaction of teachers. In the study, the aim was to determine the relationship between secondary education teachers' autonomy behaviors and their job satisfaction. 
The study which was conducted in research-review model included 354 teachers serving in the public secondary education institutions in the province of Balıkesir. Teacher Autonomy Scale (Çolak and Altınkurt, 2017) and the Job Satisfaction Scale developed by Hackman and Oldham (1975), adopted into Turkish by Silah (2002) and the validity and reliability analyses conducted on teachers by Taşdan (2008) were used for data collection. While descriptive statistics were used to determine teachers' autonomous behaviors, job satisfaction, $\mathrm{t}$ test, ANOVA, Mann Whitney U and Kruskal Wallis $\mathrm{H}$ tests were used for comparison in the study. Multiple regression analysis was used to determine whether teachers' autonomous behaviors significantly interpreted their job satisfaction.

According to the results obtained in the study, general autonomous behaviors of the teachers is above the average $(\overline{\mathrm{X}}=3.85, \mathrm{~S}=.64)$. Regarding autonomous behaviors, the highest level of participation of the teachers are found in the dimensions of communication autonomy $(\bar{X}=4.12, S=.74)$, teaching process autonomy $(\bar{X}=4.00, S=.70)$, teaching program autonomy $\bar{X}=3.71$, $\mathrm{S}=.89)$ and occupational development autonomy $(\overline{\mathrm{X}}=3.52, \mathrm{~S}=1.00)$ respectively. While teachers' opinions regarding autonomous behavior show significant difference in statistical terms in some dimensions according to the variables of gender [ $\mathrm{t}(352)=2.17 ; \mathrm{p}<.05]$, educational status $[\mathrm{t}(352)=2.47$; $\mathrm{p}<.05]$, the field of study [t(352)=2.90; $\mathrm{p}<.05]$, seniority $\left[\chi^{2}=13.18 ; \mathrm{p}<.05\right]$, age $\left[\chi^{2}=16.42 ; p<.05\right]$ and the type of school $\left[\chi^{2}=19.25 ; p<.05\right]$, there is no statistically significant difference in terms of the variables of weekly course load and duration of service at school. The teachers participating in the study are found to have a job satisfaction slightly above the average ( $\bar{X}=3.51, S=.60)$. While teachers' opinions regarding job satisfaction show statistically significant difference with respect to gender [ $t(352)=2.59 ; \mathrm{p}<.05]$, there is no statistically significant difference according to the variables of the school type, educational status, field of study, weekly course load, seniority, duration of service at school and age. A positive and moderate relationship is found between teachers' occupational communication autonomy ( $\mathrm{r}=.34$ ), occupational development autonomy $(\mathrm{r}=.31)$ and teaching process autonomy $(\mathrm{r}=.34)$ and a positive and low relationship is found between teaching program autonomy ( $\mathrm{r}=.29)$ and job satisfaction. Occupational communication autonomy and occupational development autonomy are significant factors of teachers' job satisfaction. The dimensions of teacher autonomy reveal 19\% of 
teachers' job satisfaction level $\left[R=.44 ; R^{2}=.19 ; F_{(4349)}=21.56 ; p<.05\right]$. Teachers' ability to determine the subject and time of the in-service training and their ability to participate in the scientific meetings in their fields may increase their job satisfaction. In addition, expressing their opinions freely in the teachers' board and the school administration not interfering in the communication with their colleagues and parents may increase their job satisfaction. In the literature, there are studies indicating that teachers demonstrating more autonomous behaviors have a higher level of job satisfaction. For instance, in the study conducted by Skaalvik and Skaalvik (2014), a positively oriented and low level of relationship were found between teacher autonomy and job satisfaction. In the study conducted by Pearson and Moomaw (2005), a positively oriented, low level of relationship was found between teacher autonomy and job satisfaction. Kim and Loadman (1994) have found in their study that one of the variables necessary for teachers' job satisfaction is autonomy. Perie and Baker (1997) indicated that occupational autonomy and teacher satisfaction were positively related. In the study conducted by Al-Siyabi (2016) a positively oriented, moderate relationship was found between occupational autonomy and job satisfaction. On the other hand, in a study conducted by Koustelios, Karabatzaki and Kousteliou (2004), a significant and positively oriented relationship was found between teachers' job satisfaction and autonomy. As a result, teachers' autonomy is one of the variables affecting their job satisfaction. It may be noted that teachers' participation while a teaching program is prepared and during the implementation, determining the times of the in-service training by themselves for professional development, providing availability while the students are given homework and school management's demonstrating a positive attitude while teachers are in contact with parents may increase their job satisfaction.

- Studies revealing the perception of principals on teacher autonomy and job satisfaction may be conducted.

- The research sample consists of secondary school teachers. However, the opinions of teachers serving in different levels may also be obtained.

- Studies involving different variables regarding the subject teacher autonomy may be conducted. 


\section{Kaynakça / References}

Ada, Ş. ve Şahin, C. (2007). Özerk ilköğretim okul modeli. Atatürk Üniversitesi Kazım Karabekir Ĕ̈itim Fakültesi Dergisi, 15, 341-355.

Al-Siyabi, N. S. (2016) Job autonomy and job satisfaction of English instructors in the language centers of some private colleges in Muscat, Oman. International Journal of Psychology \& Behavior Analysis, 2(111), 1-6.

Akçamete, G., Kaner, S. ve Sucuoğlu, B. (2001). Öğretmenlerde tükenmişlik, iş doyumu ve kişilik. Ankara: Nobel Yayınları.

Altınkurt, Y. ve Yılmaz, K. (2014).Öğretmenlerin mesleki profesyonelliği ile iş doyumları arasındaki ilişki. Sakarya University Journal of Education, 4(2),5771.

Anderson, L. W. (1987). The decline of teacher autonomy: Tears or cheers? International Review of Education, 33(3), 357-373.

Archbald, D. A., ve Porter, A. C. (1994). Curriculum control and teachers' perceptions of autonomy and satisfaction. Educational Evaluation and Policy Analysis, 16(1), 21-39.

Avşaroğlu, S., Deniz, M. E. ve Kahraman, A. (2005). Teknik öğretmenlerde yaşam doyumu iş doyumu ve mesleki tükenmişlik düzeylerinin incelenmesi. Selçuk Üniversitesi Sosyal Bilimler Enstitüsü Dergisi, 14, 115129.

Ayan, S., Kocacık, F. ve Karakuş, H. (2009). Lise öğretmenlerinin iş doyumu düzeyi ile bunu etkileyen bireysel ve kurumsal etkenler: Sivas merkez ilçe örneği. Anadolu Psikiyatri Dergisi, 10(1), 18-25.

Ayral, M., Özdemir, N., Türedi, A., Yılmaz-Fındık, L., Büyükgöze, H., Demirezen, S. vd. (2014). Öğretmen özerkliği ile öğrenci başarısı arasındaki ilişki: PISA örneği. Eğitim ve Bilim Araştırmaları Dergisi, 4(1), 207-218.

Balc1, A. (1983). İş doyumu ve eğitim yönetimine uygulanması. Ankara Üniversitesi Ĕ̈itim Bilimleri Fakültesi Dergisi, 16(1), 575-586.

Balçıkanlı, C. (2008). İngilizce'nin yabancı dil olarak öğrenildiği ortamlarda öğrenen özerkliği. G. Ü. Gazi Eğitim Fakültesi Dergisi, 28(3), 1-16.

Benson, P. (2010). Teacher education and teacher autonomy: Creating spaces for experimentation in secondary school English language teaching. Language Teaching Research, 14(3), 259-275.

Bernal, J. G., Castel, A. G., Navarro, M. M., ve Torres, P. R. (2005). Job satisfaction: Empirical evidence of gender differences. Women in Management Review, 20(4), 279-288. 
Bogler, R. (2001). The influence of leadership style on teacher job satisfaction. Educational Administration Quarterly, 37(5), 662-683

Boz, M. S. (2014). Ankara ili genel liselerinde görev yapan öğretmenlerin özerklik algıları ile özyeterlik algları arasındaki ilişki.Yüksek lisans tezi, Ankara Üniversitesi Eğitim Bilimleri Enstitüsü, Ankara.

Brunetti, G. J. (2001). Why do they teach? A study of job satisfaction among longterm high school teachers. Teacher Education Quarterly, 28(3), 49-74.

Büyüköztürk, Ş. (2016). Sosyal bilimler için veri analizi el kitabı. Ankara: Pegem Akademi.

Caldwell, B. J.(2005).School-based management: Educational policy series.Paris: UNESCO.

Campion, M. A., ve Thayer, P. W. (1987). Job design: Approaches, outcomes, and trade-offs. Organizational Dynamics, 15(3), 66-79.

Can, T. (2012). Yabancı dil öğretimi bağlamında öğrenen özerkliğinin sanal öğrenme ortamları yoluyla desteklenmesi. Hasan Ali Yücel Eğitim Fakültesi Dergisi, 9(1), 72-85.

Cerit, Y. (2009). The effects of servant leadership behaviours of school principals on teachers' job satisfaction. Educational Management Administration $\mathcal{E}$ Leadership, 37(5), 600-623.

Çanak, M. (2014). Ortaöğretim kurumlarında görev yapan öğretmenlerin iş doyumlarınn incelenmesi, OPUS-Türkiye Sosyal Politika ve Çalışma Hayatı Araştırmaları Dergisi, 4(7), 7-26.

Çetinkanat, C. (2000). Örgütlerde güdülenme ve iş doyumu. Ankara: Anı Yayıncılık. Çolak, İ. ve Altınkurt, Y. (2017). Okul iklimi ile öğretmenlerin özerklik davranışları arasındaki ilişki. Kuram ve Uygulamada Ĕ̆itim Yönetimi, 23(1), 33-71.

Çolak, İ., Altınkurt, Y. ve Yılmaz, K. (2017). Öğretmenlerin özerklik davranışları ile iş doyumları arasındaki ilişki. Karadeniz Sosyal Bilimler Dergisi, 8(17), 189208.

Dee, J. R., Henkin, A. B., \& Singleton, C. A. (2006). Organizational commitment of teachers in urban schools: Examining the effects of team structures. Urban Education, 41(6), 603-627.

Eğinli, A. T. (2009). Çalışanlarda iş doyumu: Kamu ve özel sektör çalışanlarının iş doyumuna yönelik bir araştırma. Atatürk Üniversitesi İktisadi ve İdari Bilimler Dergisi, 23(3), 35-52.

Fidan, T. (2007). Ankara ili ilköğretim okulu yöneticilerinin örgütsel özerkliğe ilişkin görüş ve önerileri.Yayınlanmamış yüksek lisans tezi. Ankara Üniversitesi Eğitim Bilimleri Enstitüsü, Ankara. 
Friedman, I. A. (1999). Teacher-perceived work autonomy: The concept and its measurement. Educational and Psychological Measurement, 59(1), 58-76.

Gömleksiz, M. N. ve Bozpolat, E. (2012). İlköğretimde yabancı dil öğreniminde öğrenen özerkliği. Journal of World of Turks, 4(3), 95-114.

Graham, M. W., ve Messner, P. E. (1998). Principals and job satisfaction. International Journal of Educational Management, 12(5), 196-202.

Günay, D. (2016). Öğrenen özerkliği, İngilizce öğretimine yansımaları ve Hayef örneğinde öğretmen adaylarının değişen öğretmen rolleri algısı. Hasan Ali Yücel Eğitim Fakültesi Dergisi, 13(3), 17-30.

Gür, T., Dilci, T. ve Arseven, A. (2013). Geleneksel yaklaşımdan yapılandırmacı yaklaşıma geçişte öğretmen adaylarının görüş ve değerlendirmeleri: Bir söylem analizi. Karadeniz Uluslararası Bilimsel Dergi, 18, 123-135.

Hackman, J. R., ve Oldham, G. R. (1975). Development of the job diagnostic survey. Journal of Applied Psychology, 60(2), 159-170.

Ingersoll, R. M. (2007). Short on power long on responsibility. Educational Leadership, 65(1), 20-25.

İmamoğlu, S. Z., Keskin, H. ve Erat, S. (2004). Ücret, kariyer ve yaratıcıllk ile iş tatmini arasındaki ilişkiler: Tekstil sektöründe bir uygulama. Yönetim ve Ekonomi: Celal Bayar Üniversitesi İktisadi ve İdari Bilimler Fakültesi Dergisi, 11(1), 167-176.

Keser, A. (2006). Çalışma yaşamında motivasyon. İstanbul: Alfa Aktüel Yayınları.

Kim, I., ve Loadman, W. (1994). Predicting teacher job satisfaction. (Report No: 383 707). Washington: U.S. Department of Education.

Koçak, E. (2011). İlköğretim okullarında görev yapan öğretmenlerin yetki devri, otonomi ve hesap verebilirliklerine ilişkin algılarmmn belirlenmesi.Yüksek lisans tezi. Eskişehir Osmangazi Üniversitesi Eğitim Bilimleri Enstitüsü, Eskişehir.

Koustelios, A. D., Karabatzaki, D., ve Kousteliou, I. (2004). Autonomy and job satisfaction for a sample of Greek teachers. Psychological Reports, 95(3), 883-886.

Koruklu, N., Feyzioğlu, B., Özenoğlu Kiremit, H. ve Aladağ, E. (2013). Öğretmenlerin iş doyumu düzeylerinin bazı değişkenlere göre incelenmesi. Mehmet Akif Ersoy Üniversitesi Ĕ̆itim Fakültesi Dergisi, 13(25), 119-137.

Kuku, S. M., ve J. W. Taylor. (2002). Teachers' participating in decision making: A comparative study of school leader and teacher perceptions in north Philippine academies. International Forum Journal 5(1), 19-46.

Kumaş, V. ve Deniz, L. (2010). Öğretmenlerin iş doyum düzeylerinin incelenmesi. M. Ü. Atatürk Ĕ̆itim Fakültesi Eğitim Bilimleri Dergisi, 32, 123-139. 
Lawson, T. (2004). Teacher autonomy: Power or control?. Education 3-13, 32(3), 3-18.

Little, D. (1995). Learning as dialogue: The dependence of learner autonomy on teacher autonomy. System, 23(2), 175-181.

Liu, X. S. (2007). The effect of teacher influence at school on first-year teacher attrition: A multilevel analysis of the Schools and Staffing Survey for 1999-2000. Educational Research and Evaluation, 13(1), 1-16.

Luthans, F. (2011). Organizational behavior. New York, NY: McGraw-Hill Irwin.

Organization for Economic Co-operation and Development. (2010). PISA 2009 results: What makes a school successful? - Resources, policies and practices (Volume IV). Paris, France: Author.

Oshagbemi, T. (2000). Is length of service related to the level of job satisfaction?. International Journal of Social Economics, 27(3), 213-226.

Özgüven, İ. E. (2003). Endüstri psikolojisi. Ankara: PDREM Yayınları.

Öztürk, A. ve Deniz, M. E. (2008). Okul öncesi öğretmenlerinin duygusal zekâ yetenekleri iş doyumları ve tükenmişlik düzeylerinin bazı değişkenler açısından incelenmesi. Ilköğretim Online, 7(3), 578-599.

Öztürk, İ. H. (2011).Öğretmen özerkliği üzerine kuramsal bir inceleme. Elektronik Sosyal Bilimler Dergisi, 10(35), 82-99.

Pearson, L. C., ve Hall, B. W. (1993). Initial construct validation of the teaching autonomy scale. Journal of Educational Research, 86(3), 172-178.

Pearson, L. C., ve Moomaw, W. (2005). The relationship between teacher autonomy and stress, work satisfaction, empowerment, and professionalism. Educational Research Quarterly, 29(1), 37-53.

Pehlivan, K. B. (2005). Öğretmen adaylarının iletişim becerisi algıları üzerine bir çalışma. İlköğretim Online, 4(2), 17-23.

Perie, M., ve Baker, D.P.(1997). Job satisfaction among America's teachers: Effects of workplace conditions, background characteristics, and teacher compensation.Statistical analysis report.(Report No: 412 181).Washington:U.S. Department of Education.

Porter, L. W. (1963). Job attitudes in management: IV. Perceived deficiencies in need fulfillment as a function of size of company. Journal of Applied Psychology, 47(6), 386-397.

Seferoğlu, S. S. (2004). Öğretmen yeterlikleri ve mesleki gelişim. Bilim ve Aklın Aydınlı̆̆ında Ĕ̆itim Dergisi, 58, 40-45.

Short, P. M. (1994). Defining teacher empowerment. Education, 114(4), 488-493. 
Silah, M. (2002). Sanayi işletmelerinde önemli ve çağdaş bir gereksinim: süreç danışmanliğı uygulamaları. Çukurova Üniversitesi Sosyal Bilimler Dergisi, 26(1), 143-168

Skaalvik, E. M., ve Skaalvik, S. (2014). Teacher self-efficacy and perceived autonomy: Relations with teacher engagement, job satisfaction, and emotional exhaustion. Psychological reports, 114(1), 68-77.

Skinner, R. R. (2008). Autonomy, working conditions, and teacher satisfaction: Does the public charter school bargain make a difference? (Doctoral dissertation). The George Washington University, USA.

Smith, R. C. (2003). Teacher education for teacher-learner autonomy. 15 Mayıs 2017 tarihinde

http://homepages.warwick.ac.uk/ elsdr/Teacher autonomy.pdf adresinden erişildi.

Spector, P. E. (1997). Job Satisfaction: Application, assessment, cause, and consequences. California: SAGE Publications.

Şahin, İ. (2013). Öğretmenlerin iş doyumu düzeyleri. Yüzüncü Yıl Üniversitesi Eğitim Fakültesi Dergisi, 10(1), 142-167.

Şakar, A. S. (2013). English teachers' self-perceptions of teacher autonomy in middle schools and high schools: The case of Sakarya. Yüksek lisans tezi. Çanakkale Onsekiz Mart Üniversitesi Eğitim Bilimleri Enstitüsü, Çanakkale.

Şişman, M. ve Turan, S. (2004). Bazı örgüsel değişkenler açısından çalışanların iş doyumu ve sosyal-duygusal yalnızlık düzeyleri: MEB şube müdür adayları üzerinde bir araştırma. Eskişehir Osmangazi Üniversitesi Sosyal Bilimler Dergisi, 5(1), 117-128.

Taşdan, M. (2008). Kamu ve özel ilköğretim okullarında görevli öğretmenlerin değer, iş doyumu ve öğretmene mesleki sosyal destek ile ilgili görüşleri. Doktora tezi. Ankara Üniversitesi Eğitim Bilimleri Enstitüsü, Ankara.

Taşdan, M. ve Tiryaki, E. (2008). Özel ve devlet ilköğretim okulu öğretmenlerinin iş doyumu düzeylerinin karşılaştırılması. Ĕ̆itim ve Bilim, 33(147), 54-70.

Tengilimoğlu, D. (2005). Hizmet işletmelerinde liderlik davranışları ile iş doyu$\mathrm{mu}$ arasındaki ilişkinin belirlenmesine yönelik bir araştırma. Ticaret ve Turizm Ĕ̆itim Fakültesi Dergisi, 1, 23-45.

Ulriksen, J. J. (1996). Perceptions of secondary school teachers and principals concerning factors related to job satisfaction and job dissatisfaction. (Report No: 424 684). Washington: U.S. Department of Education. 
United Nations Educational, Scientific and Cultural Organization (2017). Global education monitoring report 2017/8 - Accountability in education: Meeting our commitments. Paris: UNESCO Publishing.

Üzüm, P. ve Karslı, M. D. (2013). Sınıf öğretmenlerinin öğretmen özerkliğine ilişkin farkındalık düzeyleri:İzmir ili örneği. Inönü Üniversitesi Ĕ̆itim Fakültesi Dergisi, 14(2), 79-94.

White, P. A. (1992). Teacher empowerment under "ideal" school-site autonomy. Educational Evaluation and Policy Analysis, 14(1), 69-82.

Yaylacı, A. F. (2013). Öğretmenlerin kendilerini geliştirmelerine ilişkin yaklaşım sorunu. Uşak Üniversitesi Sosyal Bilimler Dergisi Özel Sayı, 25-40.

Yazıc, A. Ş. ve Akyol, B. (2017). Okul müdürlerinin liderlik davranışları ile öğretmen özerkliği arasındaki ilişki. Uluslararası Eğitim Bilimleri Dergisi, 4(10), 189-208.

Yıldırım, İ. (2015). Okul yöneticilerinin kişilik ve denetim odağı özelliklerinin öğretmenlerin iş doyumu ve okul etkililiği açısından incelenmesi.Doktora tezi. Atatürk Üniversitesi Eğitim Bilimleri Enstitüsü, Erzurum.

Yılmaz, E. ve Izgar, H. (2009). İlköğretimde çalışan öğretmenlerin iş doyumlarının okullardaki örgütsel yaratıcılık açısından incelenmesi. İlköğretim Online, 8(3), 943-951.

Yılmaz, K. (2012). İlköğretim okulu öğretmenlerinin iş doyumu düzeyleri ile örgütsel vatandaşlık davranışları arasındaki ilişki. Anadolu Journal of Educational Sciences International, 2(2), 1-14.

Yılmaz, K. ve Altınkurt, Y. (2012). Okul yöneticilerinin kullandıkları güç kaynakları ile öğretmenlerin iş doyumu arasındaki ilişki. Kastamonu Eğitim Dergisi, 20(2), 385-402.

Yüksel, S. (1998). Program geliştirme sürecine öğretmen katılımı. Kuram ve Uygulamada Ĕ̆itim Yönetimi Dergisi, 4(1), 99-106.

\section{Kaynakça Bilgisi / Citation Information}

Şentürken, C. ve Aytunga, O. (2020). Ortaöğretim öğretmenlerinin özerklik davranışları ile iş doyumları arasındaki ilişki. OPUSUluslararası Toplum Araştırmaları Dergisi, 15(25), 3260-3283. DOI: 10.26466/opus.650115 